\title{
Wilt of Acer negundo L. caused by Fusarium nirenbergiae in China
}

\author{
Xianghui Zhao $^{1} \cdot$ Huan $^{\mathrm{Li}^{1}} \cdot$ Lifeng $\mathrm{Zhou}^{1} \cdot$ Fei Chen ${ }^{1} \cdot$ Fengmao Chen $^{1}$
}

Received: 24 December 2018/Accepted: 3 March 2019/Published online: 17 June 2019

(C) The Author(s) 2019

\begin{abstract}
Boxelder maple (Acer negundo L.) is widely grown as ornamental trees in China. In 2017 in Pizhou, Jiangsu Province, China, the boxelder maple trees suffered from a disease which caused wilting and yellowing leaves, rotted roots, and discolored xylem. The disease broke out from July to August. Seven fungal isolates were obtained from symptomatic tissue and tested for pathogenicity. Isolate An7 was isolated at high frequency from the discolored vascular tissues, which caused the wilt disease on healthy 2-year-old seedlings after inoculation and eventually killed all the seedlings. We conducted molecular analysis for An7, including the partial sequences of the rDNA internal transcribed spacer, calmodulin, RNA polymerase II second largest subunit and the translation elongation factor $1-\alpha$ and evaluation of the variously sized conidia, chlamydospores and conidiophores and cultural traits. The pathogen was identified as Fusarium nirenbergiae, a member of the Fusarium oxysporum species
\end{abstract}

Project funding The work was supported by the National Key Research and Development Program of China (Grant Number: 2017YFD0600104).

The online version is available at http://www.springerlink.com

Corresponding editor: Tao $\mathrm{Xu}$.

Electronic supplementary material The online version of this article (https://doi.org/10.1007/s11676-019-00996-9) contains supplementary material, which is available to authorized users.

Fengmao Chen

cfengmao@njfu.edu.cn

1 Co-Innovation Center for Sustainable Forestry in Southern China, College of Forestry, Nanjing Forestry University, Nanjing, Jiangsu 210037, People's Republic of China complex. To our knowledge, this is the first report of $F$. nirenbergiae causing wilt on A. negundo in China.

Keywords Boxelder maple $\cdot$ Fusarium oxysporum species complex $\cdot$ Identification $\cdot$ Pathogenicity test

\section{Introduction}

Native to North America, boxelder maple (Acer negundo L.), has a large crown, beautiful stature and colorful fall foliage. Because of its high ornamental value, rapid growth and valuable characteristics, such as tolerance of sun exposure and a wide range of soil conditions, including salt and alkali, it is widely used for urban greening in China, especially in northern China, where the soil is poor and highly saline (Li et al. 2014). Moreover, boxelder maple also has considerable food and industrial value. It blooms in early spring and is rich in nectar, making it a valuable food source for honey bees. Bark fiber from boxelder maple can be used for papermaking, and the quality of wood is so high that it can be used for furniture and joinery (Hu and Zhai 2017). However, in Pizhou, wilt has killed hundreds of boxelder seedlings during the past 2 years, affecting the local environment and causing serious economic losses.

Several pathogens of boxelder maple have been reported. In Seville, Spain, Inonotus rickii causes canker rot disease with stem bulge and bark necrosis, and goldenbrown fungal tissue can be seen at the site of the disease, sometimes hidden under the bark (Intini 2002). In 2002 (Xinjiang Province, China) and 2006 (Turkey), pathogens associated with wilt were identified as Verticillium dahliae and Fusarium solani, respectively (Schmid and Momei 2003; Demirci and Maden 2006). Differences are obvious 
between the symptoms caused by two pathogens. $V$. dahliae, a well-known pathogen, causes rapid wilting and death, leaf drying and shedding, necrosis of twigs and discoloration of vascular tissue. Plants infected by $F$. solani show some withering of leaves and branches, and brown or red discolored areas are found in the diseased branches and sapwood, and cracks appear inside the branches of dead seedlings. Boxelder can also provide a suitable living environment for beetles, which may transmit fungi. For example, Fusarium euwallaceae, a member of the $F$. solani species complex, is transmitted by beetles and can infect and ultimately lead to tree death (Freeman et al. 2013).

$F$. oxysporum, one of the most infamous soil-borne fungal pathogens, can cause Fusarium wilt, a destructive vascular wilting in more than 100 species globally, including Eucalyptus (Wu et al. 2007), Vernicia fordii (Hua 1981), and Populus $\times$ euarmiereana (Xie et al. 1993) in China. It survives in the soil in the form of chlamydospores for several years, which germinate in response to root exudates from host plants, and forms conidia, new chlamydospores and hyphae, finally invading the hosts directly or through wounds in the roots. The hyphae then colonize the vascular tissues, and the pathogen spreads in the form of conidia within the stems. During this process, secondary fungal metabolites are secreted, which inhibit the innate immunity of the host, hampering water and nutrient transport, and causing leaf wilting and eventually death of the whole plant. As the dead plant decomposes, the pathogen returns to a dormant state in the soil until it encounters an appropriate host to infect (Nelson 1981; Goud and Hiemstra 1998).

In addition to the long survivability of the chlamydospores in the soil, the rapid speed and high mortality rates of Fusarium wilt make disease control difficult. The objectives of this study were: (1) to investigate the incidence and symptoms of the disease affecting A. negundo in Pizhou, Jiangsu Province; (2) to follow classical Koch's postulates (isolate the pathogen from diseased samples, reproduce symptom and disease progression, and recover the pathogen from inoculated plants); and (3) to identify the pathogen by morphological and molecular methods to better understand the epidemiology of the disease toward designing effective control measures.

\section{Materials and methods}

\section{Fungal isolation, purification and preservation}

From September 2017 to September 2018, planted plots of boxelder maple in Pizhou, Jiangsu Province, China were studied to understand the progression and incidence of wilt disease. Root and stem tissues were sampled from 10 symptomatic plants and washed with running tap water for about $30 \mathrm{~min}$, then surface-sterilized with $75 \%$ (v/v) ethanol for $5 \mathrm{~min}$, rinsed in sterilized water three times and dried with sterile filter paper. The discolored vascular tissues were cut into 5-mm-long segments and plated on potato dextrose agar (PDA) containing $0.1 \% \mathrm{w} / \mathrm{v}$ ampicillin to inhibit bacterial growth ( $\mathrm{Li}$ et al. 2017), then cultured in the dark at $25{ }^{\circ} \mathrm{C}$, and colony morphology, size, color and growth rate as differentiating variables, were monitored daily. Individual fungal colonies were purified by singlespore isolation, and spores were preserved and stored in $25 \%$ v/v glycerin at $-80{ }^{\circ} \mathrm{C}$ (Brady et al. 2011).

\section{Preparing of ITS sequences and phylogenetic tree of Fusarium spp.}

Except strains isolated from our study, other sequences were downloaded from GenBank (ftp://ncbi.nlm.nih.gov/ genbank/genomes/) (Table S1). The software BioEdit version 7.05 (Ibis Therapeutics, Carlsbad, CA, USA) was used to align the sequences and manually correct any bases missing from these sequences. MEGA 5.0 was used to construct a phylogenetic tree with the neighbor-joining (NJ) approach (Tamura et al. 2011), which was validated using bootstrap analyses with 1000 repetitions (Saitou and Nei 1987) based on internal transcribed spacer (ITS) sequences.

\section{Pathogenicity test}

Conidia produced by the isolates from infected tissue were prepared in Czapek liquid medium $\left(\mathrm{NaNO}_{3} 3.0 \mathrm{~g}, \mathrm{~K}_{2} \mathrm{HPO}_{3}\right.$ $1.0 \mathrm{~g}, \mathrm{MgSO}_{4} \cdot 7 \mathrm{H}_{2} \mathrm{O} 0.5 \mathrm{~g}, \mathrm{KCl} 0.5 \mathrm{~g}$, sucrose $30 \mathrm{~g}$ in $1 \mathrm{~L}$ water) and incubated at $25{ }^{\circ} \mathrm{C}$ on a shaker at $250 \mathrm{rpm}$ for at least 5 days. The fungal suspension was then passed through two layers of sterile filter cloth to obtain a spore suspension, which was adjusted to $1 \times 10^{8} / \mathrm{mL}$ with sterile water. To fulfill Koch's postulates, 2-year-old boxelder maple seedlings were grown in non-woven bags used for pathogenicity tests. Shallow wounds were cut in the roots of seedlings using a sterile blade to provide entry sites for the fungus. Each plant was watered with $50 \mathrm{~mL}$ of the conidial suspension, control plants were watered with sterile water ( $\mathrm{Li}$ et al. 2018). Each treatment and control group contained five replicates, one seedling per replicate. To replicate original growth conditions for seedlings, the plants were incubated outdoors.

After symptoms appeared on the inoculated plants, the pathogen was isolated from the roots and stems of the diseased plants, and its colony characteristics were compared with those of the original colony to verify pathogenicity. 


\section{Morphological observations}

After 5 days on PDA in the dark, morphology, color and growth rate of the culture were observed and recorded (Garcia et al. 2018), and after 10 days, chlamydospores were observed and measured (Liu et al. 2015). Pigmentation production was tested on rice culture medium $(10 \mathrm{~g}$ rice/conical flask). Conidial sporulation structures were observed when the isolates were grown on synthetic lownutrient agar $\left(\mathrm{KH}_{2} \mathrm{PO}_{3} 1.0 \mathrm{~g}, \mathrm{KNO}_{3} 1.0 \mathrm{~g}, \mathrm{MgSO}_{4} \cdot 7 \mathrm{H}_{2} \mathrm{O}\right.$ $0.5 \mathrm{~g}, \mathrm{KCl} 0.5 \mathrm{~g}$, sucrose $0.2 \mathrm{~g}$, glucose $0.2 \mathrm{~g}$, agar $15 \mathrm{~g}$ in 1-L water) for 2 days, while macroconidia and microconidia could be observed after 4 days (Krnjaja et al. 2011). The dimensions of 90 spores of each spore type were measured using a Zeiss microscope (Zeiss, Jena, Germany). The pathogen was identified according to the Booth classification system (Booth 1971).

\section{Molecular identification}

The test pathogen was cultured on PDA for 3 days at $25^{\circ} \mathrm{C}$, then genomic DNA was isolated using the cetyltrimethylammonium bromide (CTAB) method (Möller et al. 1992). Briefly, hyphae were cut up and placed in a sterile Eppendorf tube with $500 \mu \mathrm{L}$ each of chloroform and $2 \% \mathrm{CTAB}$, then shaken for $1.5 \mathrm{~h}$ at $200 \mathrm{rpm}$, before being centrifuged at $4{ }^{\circ} \mathrm{C}, 13,000 \times g$ for $10 \mathrm{~min}$. The supernatant $(300 \mu \mathrm{L})$ was transferred to another tube with $600 \mu \mathrm{L}$ ethanol, then centrifuged at $4{ }^{\circ} \mathrm{C}$ and $13,000 \times g$ for $5 \mathrm{~min}$. The supernatant was discarded, and the pellet was washed twice with $75 \%(\mathrm{v} / \mathrm{v})$ ethanol. After the ethanol was volatilized, $50 \mu \mathrm{L}$ sterile deionized water was added to the pellet to obtain a crude DNA suspension.

For identifying the species of the Fusarium isolate, the ITS and the calmodulin ( $\mathrm{cmdA}$ ), RNA polymerase II second largest subunit $(R B P 2)$, and translation elongation factor 1- $\alpha(T E F-1 \alpha)$ genes were amplified using the primer pairs in Table 1 . The $50-\mu \mathrm{L}$ polymerase chain reaction (PCR) volume contained $25 \mu \mathrm{L}$ Mix (Vazyme, Nanjing, China), $17 \mu \mathrm{L} \mathrm{ddH_{2 }} \mathrm{O}, 4 \mu \mathrm{L}$ DNA and $2 \mu \mathrm{L}$ of each primer.
The PCR reaction conditions for the ITS, $c m d A$, and TEF- $1 \alpha$ were $95{ }^{\circ} \mathrm{C}$ for $5 \mathrm{~min} ; 35$ cycles of $94{ }^{\circ} \mathrm{C}$ for $30 \mathrm{~s}$, $58{ }^{\circ} \mathrm{C}$ for $30 \mathrm{~s}, 72{ }^{\circ} \mathrm{C}$ for $45 \mathrm{~s}$; and $72{ }^{\circ} \mathrm{C}$ for $10 \mathrm{~min}$. For $R P B 2$, the conditions were $95{ }^{\circ} \mathrm{C}$ for $5 \mathrm{~min}$; 35 cycles of $94{ }^{\circ} \mathrm{C}$ for $30 \mathrm{~s}, 58{ }^{\circ} \mathrm{C}$ for $30 \mathrm{~s}$ and $72{ }^{\circ} \mathrm{C}$ for $1.5 \mathrm{~min}$; and $72{ }^{\circ} \mathrm{C}$ for $10 \mathrm{~min}$. For each sequence, the amplified product was detected by gel electrophoresis on $1 \%$ agarose. Primer synthesis and nucleic acid sequencing of PCR products were carried out by Shanghai Jieli Biotechnology Corporation (Shanghai, China).

The ITS sequence was used in a BLAST search of the GenBank database (National Center for Biotechnology Information, National Institutes of Health, Bethesda, MD, USA; http://www.ncbi.nlm.nih.gov) to initially determine its identity. The $c m d A, R P B 2$ and $T E F-1 \alpha$ sequences of other species in the Fusarium oxysporum species complex (FOSC) were downloaded from NCBI to use in a cluster analysis (Table 2). The software BioEdit version 7.05 (Ibis Therapeutics, Carlsbad, CA, USA) was used to align the sequences and manually correct any bases missing from these sequences. MEGA 5.0 was used to construct a phylogenetic tree with the neighbor-joining (NJ) approach (Tamura et al. 2011), which was validated using bootstrap analyses with 1000 repetitions (Saitou and Nei 1987) based on the $c m d A, R P B 2$ and $T E F-1 \alpha$ sequences.

\section{Results}

\section{Field studies on progression and characteristics of the disease}

In recent years, as a result of poor management, low soil permeability, high planting density and other factors, diseases of boxelder maple, especially wilt, have become increasingly serious. In July 2017, some of the trees in Pizhou, Jiangsu Province showed the symptoms of wilt. Wilt symptoms first occurred in early May, reached their peak in July and August, and lasted until September. Disease progression was rapid. The pathogen infected seedlings of different ages, resulting in death within a short
Table 1 Primer sequences used for molecular identification of fungus causing wilt disease of boxelder

\begin{tabular}{lll}
\hline Primer name & Sequence $\left(5^{\prime}\right.$ to $\left.3^{\prime}\right)$ & References \\
\hline ITS1 & TCCGTAGGTGAACCTGCGG & White et al. (1994) \\
ITS4 & TCCTCCGCTTATTGATATGC & \\
Cal228F & GAGTTCAAGGAGGCCTTCTCCC & Carbone and Kohn (1999) \\
CAL2Rd & TGRTCNGCCTCDCGGATCATCTC & Groenewald et al. (2013) \\
5f2 & GGGGAGATCAGAAGAAGGC & Liu et al. (1999) and Sung et al. (2007) \\
7cr & CCCATAGCTTGTTTACCCAT & \\
EF-1Ha & ATGGGTAAGGAAGACAAGAC & O'Donnell et al. (1998) \\
EF-2 Tb & GGAAGTACCAGTGATCATGTT & \\
\hline
\end{tabular}


Table 2 Related reference strains of Fusarium species used for phylogenetic analysis

\begin{tabular}{|c|c|c|c|c|}
\hline \multirow[t]{2}{*}{ Strain } & \multirow[t]{2}{*}{ Species name } & \multicolumn{3}{|c|}{ GenBank accessions } \\
\hline & & $c m d A$ & $R P B 2$ & $T E F 1$ \\
\hline CBS 187.53 & Fusarium callistephi & MH484693 & MH484875 & MH484966 \\
\hline CBS 115423 & F. callistephi & MH484723 & MH484905 & MH484996 \\
\hline CBS $144739=$ CPC 25792 & F. carminascens & MH484752 & MH484934 & MH485025 \\
\hline CBS $144740=$ CPC 25793 & F. carminascens & MH484753 & MH484935 & MH485026 \\
\hline CBS $144741=$ CPC 25795 & F. carminascens & MH484754 & MH484936 & MH485027 \\
\hline CBS $144738=$ CPC 25800 & F. carminascens & MH484755 & MH484937 & MH485028 \\
\hline CBS 111552 & F. contaminatum & MH484718 & MH484900 & MH484991 \\
\hline CBS 114899 & F. contaminatum & MH484719 & MH484901 & MH484992 \\
\hline CBS 117461 & F. contaminatum & MH484729 & MH484911 & MH485002 \\
\hline CBS $620.72=$ DSM $11271=$ NRRL 36520 & F. cugenangense & MH484697 & MH484879 & MH484970 \\
\hline CBS $130304=$ BBA $69050=$ NRRL 25433 & F. cugenangense & MH484739 & MH484921 & MH485012 \\
\hline CBS $130308=$ ATCC 26225 = NRRL 25387 & F. cugenangense & MH484738 & MH484920 & MH485011 \\
\hline CBS 131393 & F. cugenangense & MH484746 & MH484928 & MH485019 \\
\hline CBS $247.61=$ BBA $8398=$ DSM $62308=$ NRRL 22545 & F. curvatum & MH484694 & MH484876 & MH484967 \\
\hline CBS $141.95=$ NRRL $36251=$ PD 94/1518 & F. curvatum & MH484712 & MH484894 & MH484985 \\
\hline CBS $102026=$ NRRL 36115 & F. duoseptatum & MH484714 & MH484896 & MH484987 \\
\hline CBS $217.49=$ NRRL 36358 & F. elaeidis & MH484688 & MH484870 & MH484961 \\
\hline CBS $218.49=$ NRRL 36359 & F. elaeidis & MH484689 & MH484871 & MH484962 \\
\hline CBS $255.52=$ NRRL 36386 & F. elaeidis & MH484692 & MH484874 & MH484965 \\
\hline CBS $144743=$ CPC 25802 & F. fabacearum & MH484757 & MH484939 & MH485030 \\
\hline CBS $144744=$ CPC 25803 & F. fabacearum & MH484758 & MH484940 & MH485031 \\
\hline CBS 120665 & $F$. foetens & MH484736 & MH484918 & MH484918 \\
\hline CBS $176.33=$ NRRL 36286 & F. glycines & MH484686 & MH484868 & MH484959 \\
\hline CBS 200.89 & F. glycines & MH484706 & MH484888 & MH484979 \\
\hline CBS $144746=$ CPC 25808 & F. glycines & MH484760 & MH484942 & MH485033 \\
\hline CBS 116611 & F. gossypinum & MH484725 & MH484907 & MH484998 \\
\hline CBS 116613 & F. gossypinum & MH484727 & MH484909 & MH485000 \\
\hline CBS 132476 & F. hoodiae & MH484748 & MH484930 & MH485021 \\
\hline CBS 132477 & F. hoodiae & MH484749 & MH484931 & MH485022 \\
\hline CBS $645.78=$ NRRL 36531 & F. languescens & MH484698 & MH484880 & MH484971 \\
\hline CBS $646.78=$ NRRL 36532 & F. languescens & MH484699 & MH484881 & MH484972 \\
\hline CBS $413.90=$ ATCC $66046=$ NRRL 36465 & F. languescens & MH484708 & MH484890 & MH484981 \\
\hline CBS $300.91=$ NRRL 36416 & F. languescens & MH484709 & MH484891 & MH484982 \\
\hline CBS $872.95=$ NRRL 36570 & F. languescens & MH484713 & MH484895 & MH484986 \\
\hline CBS 119796 = MRC 8437 & F. languescens & MH484735 & MH484917 & MH485008 \\
\hline CBS $144747=$ CPC 25788 & F. libertatis & MH484751 & MH484933 & MH485024 \\
\hline CBS $144749=$ CPC 28465 & F. libertatis & MH484762 & MH484944 & MH485035 \\
\hline CBS 127.81 = BBA 63924 = NRRL 36229 & F. nirenbergiae & MH484701 & MH484883 & MH484974 \\
\hline CBS $115416=$ CPC 5307 & F. nirenbergiae & MH484720 & MH484902 & MH484993 \\
\hline CBS 115417 = CPC 5306 & F. nirenbergiae & MH484721 & MH484903 & MH484994 \\
\hline CBS $123062=$ GJS 91-17 & F. nirenbergiae & MH484737 & MH484919 & MH485010 \\
\hline CBS $794.70=$ BBA $11103=$ NRRL 22550 & F. odoratissimum & MH484696 & MH484878 & MH484969 \\
\hline CBS 102030 & F. odoratissimum & MH484716 & MH484898 & MH484989 \\
\hline CBS $130310=$ NRRL 25603 & F. odoratissimum & MH484740 & MH484922 & MH485013 \\
\hline CBS 221.49 = IHEM 4508 = NRRL 22546 & F. oxysporum & MH484690 & MH484872 & MH484963 \\
\hline CBS 144135 & F. oxysporum & MH484772 & MH484954 & MH485045 \\
\hline CPC 25822 & F. oxysporum & MH484761 & MH484943 & MH485034 \\
\hline
\end{tabular}


Table 2 continued

\begin{tabular}{|c|c|c|c|c|}
\hline \multirow[t]{2}{*}{ Strain } & \multirow[t]{2}{*}{ Species name } & \multicolumn{3}{|c|}{ GenBank accessions } \\
\hline & & $c m d A$ & $R P B 2$ & $T E F 1$ \\
\hline CBS $144750=$ CPC 30822 & F. pharetrum & MH484769 & MH484951 & MH485042 \\
\hline CBS $144751=$ CPC 30824 & F. pharetrum & MH484770 & MH484952 & MH485043 \\
\hline CBS $102028=$ NRRL 36117 & F. trachichlamydosporum & MH484715 & MH484897 & MH484988 \\
\hline CBS 116619 & F. triseptatum & MH484728 & MH484910 & MH485001 \\
\hline CBS 119665 & F. triseptatum & MH484734 & MH484916 & MH485007 \\
\hline CBS 177.31 & F. udum & MH484684 & MH484866 & MH484957 \\
\hline NRRL 62542 & F. veterinarium & MH484765 & MH484947 & MH485038 \\
\hline NRRL 62545 & F. veterinarium & MH484766 & MH484948 & MH485039 \\
\hline NRRL 62547 & F. veterinarium & MH484767 & MH484949 & MH485040 \\
\hline CBS $128.81=$ BBA $63925=$ NRRL 36233 & Fusarium sp. & MH484702 & MH484884 & MH484975 \\
\hline CBS $680.89=$ NRRL 26221 & Fusarium sp. & MH484707 & MH484889 & MH484980 \\
\hline CBS 130323 & Fusarium sp. & MH484745 & MH484927 & MH485018 \\
\hline
\end{tabular}

time. Normally, leaves senesce and fall in November. However, when the disease started, the leaves sporadically turned yellow (Fig. 1b). In later stages, most leaves became brown, withered and shrunken, falling off prematurely. The twigs became necrotic, and finally the seedling died
(Fig. 1c, d). The phloem turned light brown in the longitudinal direction (Fig. 1e), with longitudinal sections of xylem showing reddish-brown and lavender in color (Fig. 1f). The intact root was reddish brown or purple,
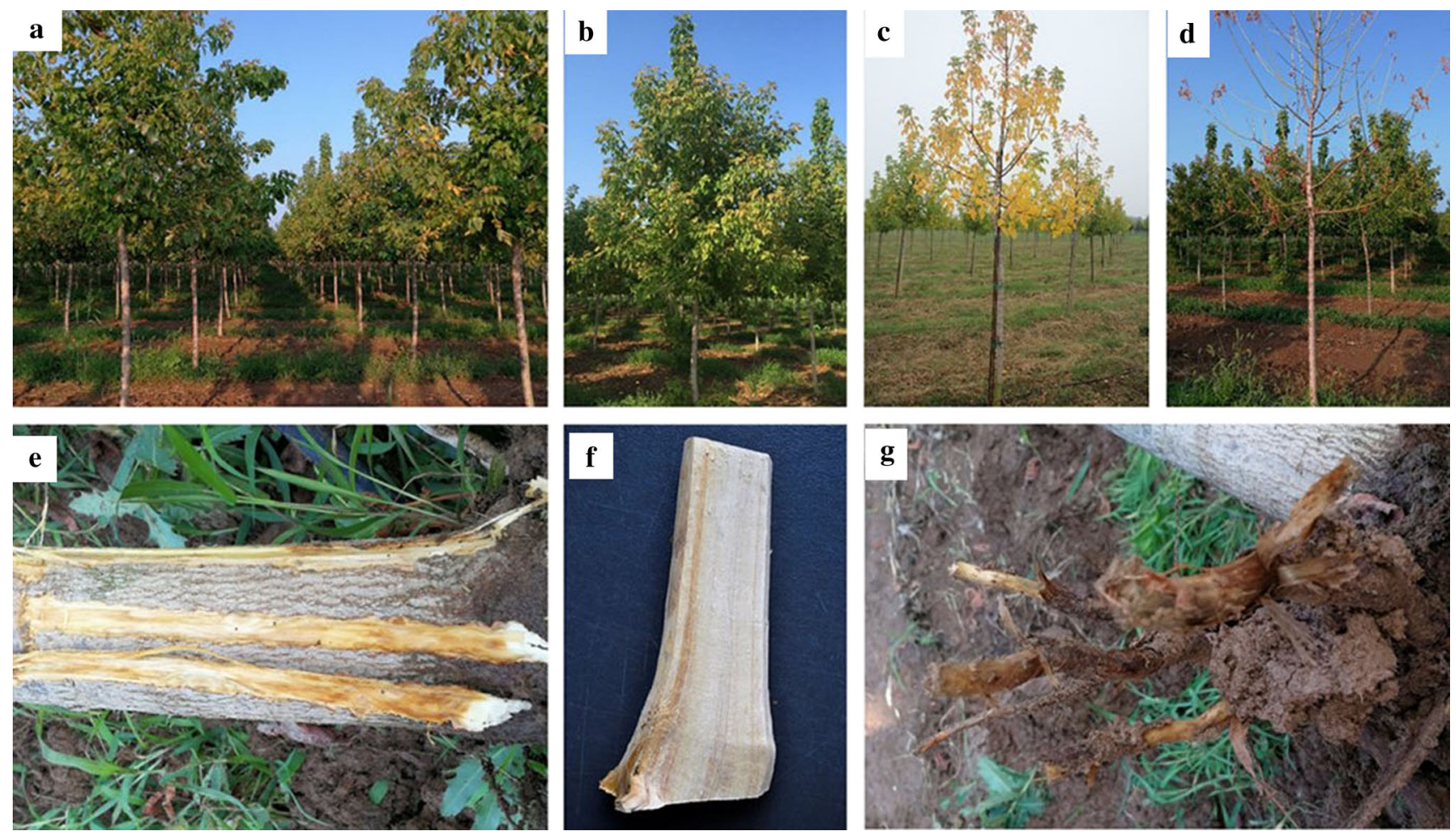

Fig. 1 Symptoms of fusarium wilt in Acer negundo L. a Planted plot; b early symptoms; c Later symptoms; d dead plant; e discolored phloem; f longitudinal section of xylem; $\mathbf{g}$ roots of diseased plant 
epidermis was rotted and had exfoliated, and the root surface became fibrous and flocculent (Fig. 1g).

\section{Fungal isolation and pathogenicity tests}

Among the 80 single-spore isolates obtained, most were morphologically similar to Fusarium spp. Because of the diversity of Fusarium species, ITS sequencing and phylogenetic analysis (Fig. S1) of these strains performed, and the result showed that there were Fusarium equiseti, $F$. oxysporum, $F$. proliferatum, $F$. solani and $F$. tricinctum, others were Bipolaris shoemakeri, Botryosphaeria dothidea. These strains isolated at a frequency of $5,10,15,5$, 10, 10, and 45\%, and named An1 to An7, respectively. (GenBank accessions of isolated Fusarium spp. and morphological characteristics were shown in Tables S2, S3-S6 and Figs. S2-S6.)

In the pathogenicity tests on healthy 2 -year-old seedlings (5 each/fungal isolate), only isolate An7 caused symptoms, and controls were symptom-free (Fig. 2a). With An7, after 42 days, one seedling showed wilt symptoms (Fig. 2b) and died on day 46; the other four seedlings died on day 49, 52, 55 and 60 , respectively. The roots of the dead plants were rotted and fibrous and easily exfoliated.
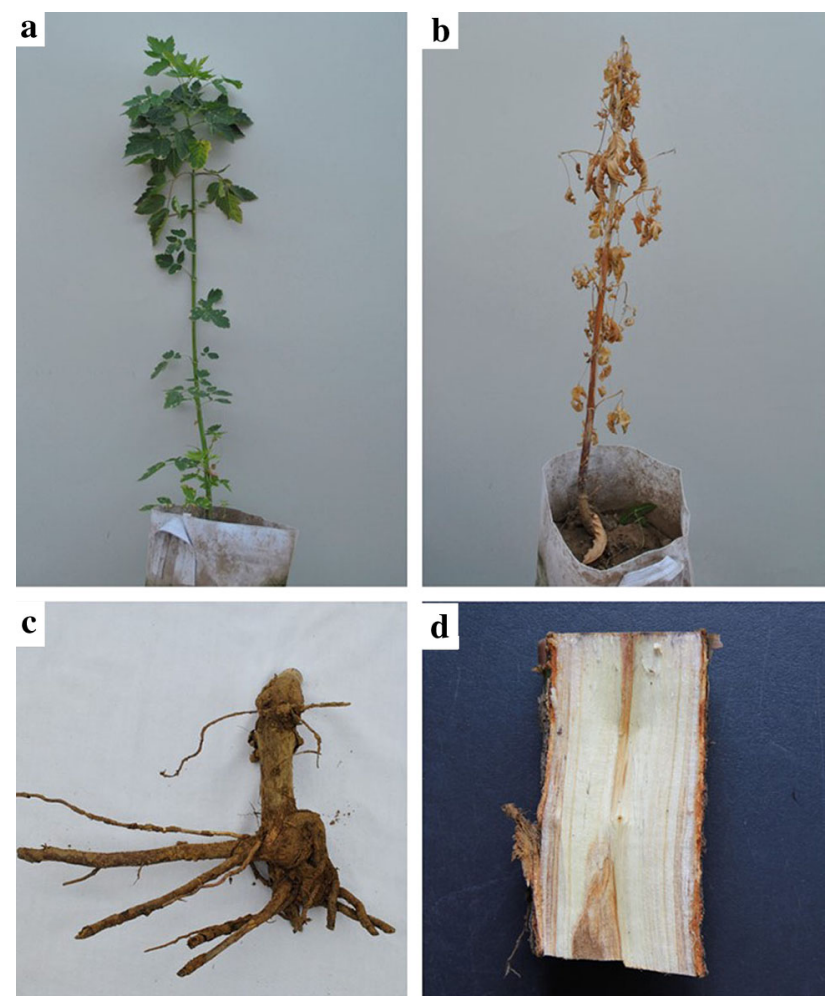

Fig. 2 Symptoms on 2-year-old boxelder maple saplings after inoculation with isolate An7. a Control treated with water. b Diseased sapling, c roots of diseased sapling, d longitudinal longitudinal section from stem of diseased sapling 46 days after inoculation with $\mathrm{An} 7$
The cortex in some of the lateral roots was reddish-brown or lavender, and the stem had a distinct reddish-brown or lavender discoloration in longitudinal section (Fig. 2c, d). These symptoms resembled those on naturally infected diseased plants in the field. Isolate An7 was consistently reisolated from the roots and stems of all symptomatic seedlings and thus, determined to be the causative agent of A. negundo wilt.

\section{Morphology}

The pathogen grew moderately well on PDA; colony diameter was $6.4 \mathrm{~cm}$ after 5 days in the dark at $25^{\circ} \mathrm{C}$. At first, the colony was white with abundant and flocculent aerial hyphae, but later turned light purple (Fig. 3a, b). A purple pigment was also produced on rice culture medium. Microconidia were abundant, ovate, oval or kidney-shaped, 1-2-celled, with 0-2 septa (Fig. 4a-c). Macroconidia were less abundant, and in the shape of orange petal spindles, or sickles. The macroconidia had tapered, slightly curved apical cells and foot-shaped cells at the base (Fig. 4d-f). Macroconidia most commonly had three septa. Hyphae were septate, and spores were borne on long or short conidiophores, mostly with single branches (Fig. 4g). After 10 days on PDA, globose, thick- and smooth-walled chlamydospores were produced, intercalary or solitary, commonly single, but sometimes chained (Fig. 4h). Spores dimensions are given in Table 3.

On the basis of colony morphology and color, conidial characteristics including the pedicel and chlamydospore characteristics, the pathogen was identified as $F$. oxysporum (Booth 1971).

\section{Molecular identification}

After PCR amplification with primers ITS1/ITS4, Cal228F/ CAL2Rd, 5f2/7cr and EF1H/EF2T, fragments of 529, 604, 936 and 576 bp were obtained, respectively (GenBank accessions MH990908, MK495366, MK495367, MK011886, respectively). The ITS sequence of the test pathogen $100 \%$ similarity with that of $F$. oxysporum in the BLAST search.

In the phylogenetic tree based on the $c m d A, R P B 2$ and $T E F-1 \alpha$ sequences of the test pathogen and other FOSC strains (number of sites $=590$, bootstrap replicates $=1000)$, the 60 strains of Fusarium species were clearly divided into several clades, representing different species within the FOSC (Fig. 5). The test pathogen had highest similarity with Fusarium nirenbergiae rather than Fusarium curvatum. Therefore, the pathogen was confirmed to be $F$. nirenbergiae. 
Fig. 3 Colony of Fusarium oxysporum isolated from Acer negundo cultured after 5 days on PDA at $25^{\circ} \mathrm{C}$. a Top and b reverse view
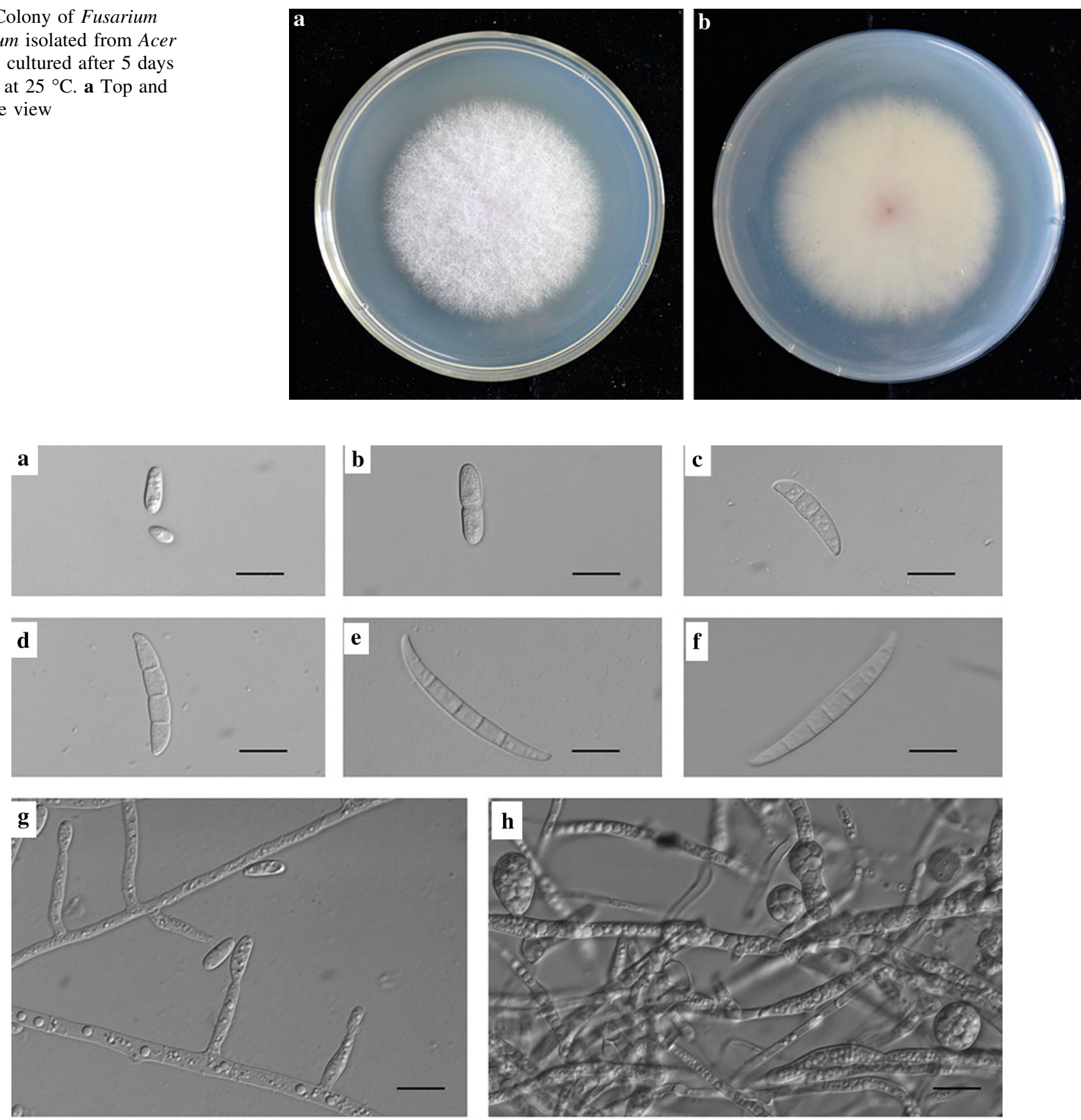

Fig. 4 Micro- and macroconidia, conidiophores and chlamydospores of Fusarium oxysporum. a, b Microconidia; c-f macroconidia with 2-5 cells; $\mathbf{g}$ conidiophores; $\mathbf{h}$ chlamydospores and hyphae. Scale bars, $10 \mu \mathrm{m}$

\section{Discussion}

To the best of our knowledge, this is the first report of wilt on $A$. negundo caused by $F$. nirenbergiae in China. The FOSC has more than 150 putative plant host-specific formae speciales (Araújo et al. 2017), such as $F$. oxysporum $\mathrm{f}$. sp. elaeidis, the aetiological agent of Fusarium wilt of oil palm (Flood 2006). In India, F. oxysporum f. sp. ciceri can cause chickpea wilt (Barve et al. 2001). Zhou et al. (2010) found $F$. oxysporum f. sp. niveum race 3 was the high virulent race to cause the watermelon wilt.
Identifying Fusarium species is difficult because of their similar morphology and conservation of gene sequences. Identification on the basis of ITS sequence is not sufficiently accurate. Thus, $28 \mathrm{~S}$ ribosomal RNA large subunit sequence, intergenic spacer region of the rDNA regions, the mitochondrial small subunit, and some protein-encoding genes, such as the $c m d A, R P B 2, T E F-1 \alpha$ and $\beta$-tubulin have also been used. Although a single gene locus can sometimes identify a species, in other cases, multiple gene loci are often needed for identification (Yli-mattila et al. 2004). Correlation analysis of the above conserved genes 
Table 3 Dimensions of the various spore types of isolate An7 that caused wilt disease of boxelder

\begin{tabular}{lr}
\hline Spore type & \multicolumn{1}{c}{ Length $($ range $) \times$ diameter $($ range $), \mu \mathrm{m}$} \\
\hline 0 septum & $7.972(4.372-16.413) \times 3.748(2.753-8.377)$ \\
1 septum & $13.155(5.966-20.857) \times 4.245(2.806-5.507)$ \\
2 septa & $17.611(10.075-24.587) \times 5.133(3.254-6.170)$ \\
3 septa & $25.093(16.442-35.575) \times 4.503(3.552-5.423)$ \\
4 septa & $40.104(35.417-45.744) \times 4.421(3.561-5.764)$ \\
5 septa & $42.669(38.672-46.553) \times 4.358(3.561-5.375)$ \\
Chlamydospore & $7.811(4.196-14.196) \times 7.556(4.062-14.462)$ \\
\hline
\end{tabular}

Microconidia: 0 or 1 septum; macroconidia: $2-5$ septa

can effectively reduce errors caused by comparing single gene sequences. Lombard et al. (2019) clarified the taxonomy of $F$. oxysporum using four gene fragments, $\mathrm{cmdA}$, RPB2, TEF- $1 \alpha$ and $\beta$-tubulin. We thus used this method to identify the pathogen as $F$. nirenbergiae, a member of FOSC. The 0-septate conidia, macroconidia and chlamydospore characteristics of pathogen are similar to the characteristics of $F$. nirenbergiae, but the colony morphology, other conidia, conidiophores differed slight differed. Furthermore, according to Lombard et al. (2019) and the phylogenetic tree, $F$. nirenbergiae is closely related to $F$. curvatum, but we can distinguish them by morphology. $F$. curvatum produces strongly curved 3-septate macroconidia and aerial polyphialidic conidiogenous cells, whereas the aerial phialides of $F$. nirenbergiae re subcylindrical, and the macroconidia are slight curving, taperin at both ends. On SNA, F. curvatum does not produce chlamydospores, but $F$. nirenbergiae produces nearly spherical chlamydospores.

For many pathogens, temperature plays a decisive role in growth. During the infection cycle of $V$. dahliae, high summertime temperatures can eliminate the pathogen from infected host plants, which then recover during the summer (Goud 2003). Unexpectedly, the outbreak period of the A. negundo Fusarium wilt was in mid to late summer, from July to August. However, in our later experiment, spores germinated below $58{ }^{\circ} \mathrm{C}$. High temperature did not inhibit spore germination, but increases transpiration in plants, which is more conducive to the spread of spores in the vascular tissues, and the outbreak of Fusarium wilt is consequently serious.

Research into the pathogenesis of Fusarium wilt has mainly focused on cell-wall-degrading enzymes (Jonkers et al. 2009; King et al. 2011) and toxins (Bani et al. 2014). In boxelder, the root cortex was degraded, likely by cellwall-degrading enzymes produced by the fungus. $F$. oxysporum can secrete extracellular metabolites during its growth, which can impair the permeability of the

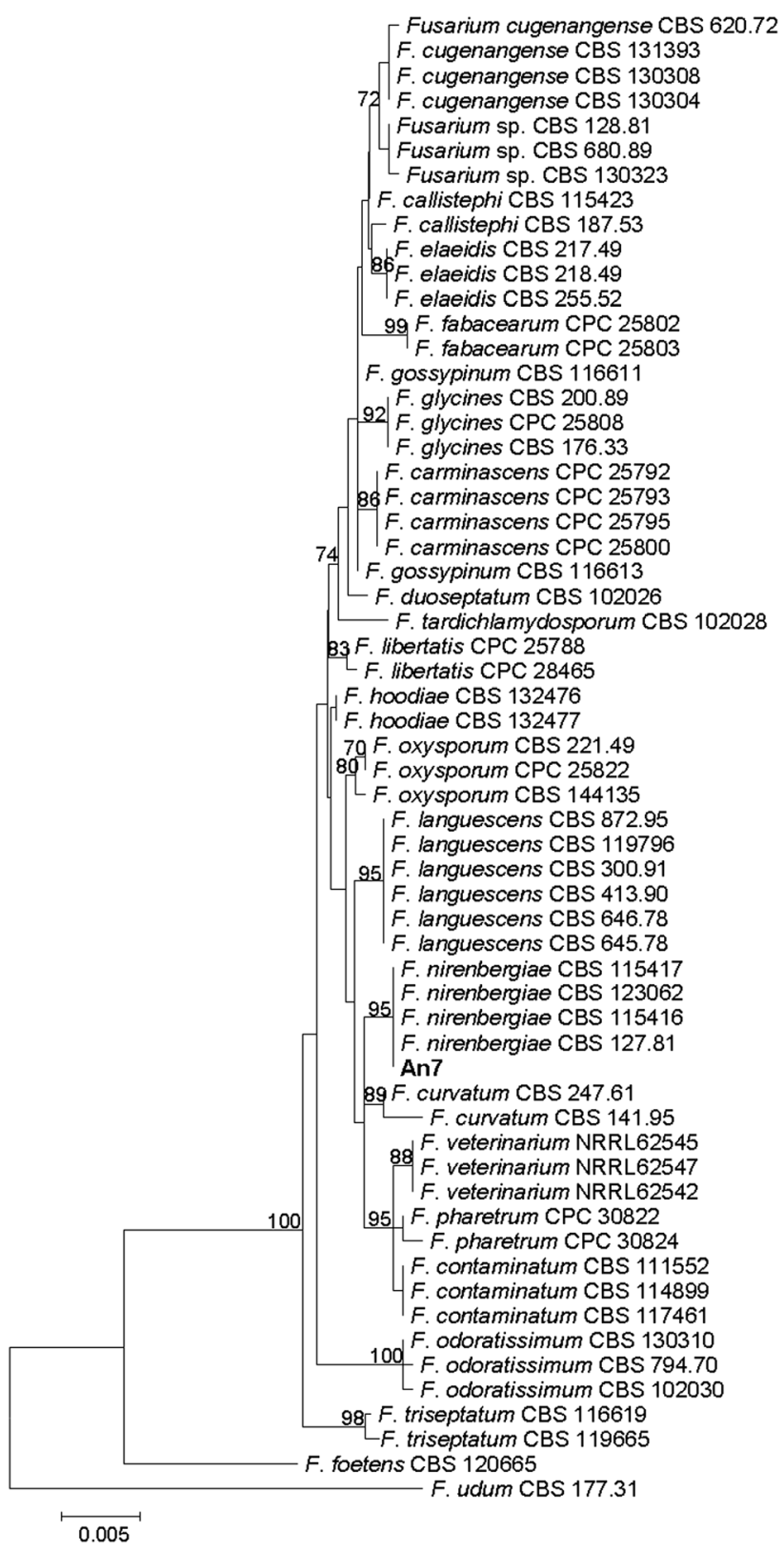

Fig. 5 Phylogenetic tree of isolate An7 of Fusarium nirenbergiae and Fusarium accessions from GenBank constructed based on $c m d A$, $R P B 2, E F-1 \alpha$ gene sequences

cytoplasmic membrane of the host and undermine the plant's immune response, thus causing metabolic disorders in the plant, which ultimately dies (Singh 1971; Jonkers et al. 2009). These metabolites include toxins such as fusaric acid and trichothecenes, which can destroy the membranes in the root system and inhibit the defense and functioning of the root system, resulting in rapid wilting of the plant (Pei et al. 2014). Deoxynivalenol exhibits strong phytotoxicity and accelerates the spread of the pathogen, while the trichothecenes can cause symptoms such as plant 
wilting, chlorosis and blight, and inhibit protein synthesis (Shi et al. 1997).

Additional questions about the wilt of boxelder still need to be answered, including whether the pathogen is a hostspecific pathogen of $A$. negundo, identifying the origin of the pathogen and its pathogenic mechanism. Maple, as a common ornamental tree species, is widely cultivated in China. The identification of this pathogen provides a reference for planting and management of this species. The identification of the causative pathogen of A. negundo Fusarium wilt will lead to improved detection of infested soils and sites for planting and the rationalization of fertilizer and fungicide applications, which may contribute to the reduction or prevention of the disease.

Open Access This article is distributed under the terms of the Creative Commons Attribution 4.0 International License (http://crea tivecommons.org/licenses/by/4.0/), which permits unrestricted use, distribution, and reproduction in any medium, provided you give appropriate credit to the original author(s) and the source, provide a link to the Creative Commons license, and indicate if changes were made.

Author's contributions X.H. Zhao and H. Li contributed equally to this work and should be considered co-first authors.

\section{References}

Araújo NAF, Pasqual M, Pio LAS, Alves E, Moura NM, Costa SS (2017) Identification and aggressiveness of four isolates of Fusarium oxysporum f.sp. cubense from Latundan banana in Brazil. J Phytopathol 165:257-264

Bani M, Rispail N, Evidente A, Rubiales D, Cimmino A (2014) Identification of the main toxins isolated from Fusarium oxysporum f. sp. pisi race 2 and their relation with isolates' pathogenicity. J Agric Food Chem 62:2574-2580

Barve MP, Haware MP, Sainani MN, Ranjekar PK, Gupta VS (2001) Potential of microsatellites to distinguish four races of Fusarium oxysporum f. sp. ciceri prevalent in India. Theor Appl Genet 102:138-147

Booth C (1971) The genus Fusarium. Commonwealth Agricultural Bureaux, Kew

Brady CR, Noll LW, Saleh AA, Little CR (2011) Disease severity and microsclerotium properties of the sorghum sooty stripe pathogen, Ramulispora sorghi. Plant Dis 95:853-859

Carbone I, Kohn LM (1999) A method for designing primer sets for speciation studies in filamentous ascomycetes. Mycologia 91:553-556

Demirci E, Maden S (2006) A severe dieback of box elder (Acer negundo) caused by Fusarium solani (Mart.) Sacc. in Turkey. Australas Plant Dis Notes 1:13-15

Flood J (2006) A review of Fusarium Wilt of oil palm caused by Fusarium oxysporum f. sp. elaeidis. Phytopathology 96:660-662

Freeman S, Sharon M, Maymon M, Mendel Z, Protasov A, Aoki T, Eskalen A, O'Donnell K (2013) Fusarium euwallaceae sp. nov.-a symbiotic fungus of Euwallacea sp., an invasive ambrosia beetle in Israel and California. Mycologia 105(6):1595-1606

Garcia R, Rivera-Vargas LI, Ploetz R, Correll JC, Irish BM (2018) Characterization of Fusarium spp. isolates recovered from bananas (Musa spp.) affected by Fusarium wilt in Puerto Rico. Eur J Plant Pathol 152:599-611

Goud JC (2003) Chapter 1: general introduction. In: Goud JC (ed) Verticillium wilt in trees: detection, prediction and disease management. Bij Wageningen Universiteit, Wageningen, pp 1-9

Goud JC, Hiemstra JA (1998) Verticillium wilt of major tree hosts: other tree species. In: Hiemstra, Harris (eds) A compendium of verticillium wilts in tree species. Ponsen \& Looijen, Wageningen, pp 37-39

Groenewald JZ, Nakashima C, Nishikawa J, Shin HD, Park JH, Jama AN, Groenewald M, Braun U, Crous PW (2013) Species concepts in Cercospora: spotting the weeds among the roses. Stud Mycol 75:115-170

Hu DZ, Zhai J (2017) Cultivation technique of Acer negundo L. Inf Agric Sci Technol 5:102-103

Hua SL (1981) Research on Fusarium wilt of Vernicia fordii. J Nanjing For Univ (Nat Sci) 3:45-53

Intini M (2002) First report of Inonotus rickii causing canker rot on boxelder in Europe. Plant Dis 86:922

Jonkers W, Rodrigues CD, Rep M (2009) Impaired colonization and infection of tomato roots by the $\Delta \mathrm{frp} 1$ mutant of Fusarium oxysporum correlates with reduced CWDE gene expression. Mol Plant Microbe Interact 22:507-518

King BC, Waxman KD, Nenni N, Walker LP, Bergstrom G, Gibson DM (2011) Arsenal of plant cell wall degrading enzymes reflects host preference among plant pathogenic fungi. Biotechnol Biofuels 4:1-14

Krnjaja V, Lević J, Stanković S, Bijelić Z (2011) Occurrence of Fusarium species in maize grains for silage. Plant Breed Seed Sci 63:103-108

Li HY, Liu T, Zhang HX, Yang XY (2014) Cutting propagation technique of Acer negundo L. J Northeast For Univ 8:25-29

Li PL, Shi YX, Guo MY, Xie XW, Chai AL, Li BJ (2017) Fusarium wilt of cauliflower caused by Fusarium equiseti in China. Can J Plant Path 39:77-82

Li H, Zhou LF, Wang LC, Zhao XH, Liang L, Chen FM (2018) Wilt of shantung maple caused by Verticillium dahliae in China. Plant Dis Notes 102:249

Liu YJ, Whelen S, Hall BD (1999) Phylogenetic relationships among ascomycetes: evidence from an RNA polymerse II subunit. Mol Biol Evol 16:1799-1808

Liu KC, Xu W, Yu SJ, Li Y, Han ZM (2015) Investigations on blight disease of Zelkova schneideriana and pathogen identification. J Nanjing For Univ (Nat Sci) 39:24-28

Lombard L, Sandoval-Denis MP, Lamprecht SC, Crous PW (2019) Epitypification of Fusarium oxysporum - clearing the taxonomic chaos. Persoonia 43:1-47

Möller EM, Bahnweg G, Sandermann H, Geiger HH (1992) A simple and efficient protocol for isolation of high molecular weight DNA from filamentous fungi, fruit bodies, and infected plant tissues. Nucleic Acids Res 20:6115-6116

Nelson PE (1981) Life cycle and epidemiology of Fusarium oxysporum. In: Marshall EM (ed) Fungal wilt diseases of plants. Academic Press, New York, pp 51-78

O’Donnell K, Kistler HC, Cigelnik E, Ploetz R (1998) Multiple evolutionary origins of the fungus causing panama disease of banana: concordant evidence from nuclear and mitochondrial gene genealogies. Appl Biol Sci 95:2044-2049

Pei YL, Zeng FY, Peng J, Long HB, Rong J (2014) Research on the progress of interaction mechanism between Fusarium oxysporum and host. J Trop Biol 5:92-100

Saitou N, Nei M (1987) The neighbor-joining method: a new method for reconstructing phylogenetic trees. Mol Biol Evol 4:406-425

Schmid R, Momei C (2003) Major forest tree pathogens in China. In: Chen MM (ed) Forest fungi phytogeography of China, North America, and Siberia, and international quarantine of tree 
pathogens. International Association for Plant Taxonomy, Kensington, pp 328-329

Shi JR, Wang YZ, He CY, Jinsheng Wang (1997) Fusarium trichothecene toxins their function in plant diseases. J Plant Pathol 4:298-302

Singh D (1971) Effect of alanine in development of Verticillium wilt in cotton cultivars with different levels of resistance. Phytopathology 61:881-882

Sung G, Sung J, Hywel-Jones NL, Spatafora JW (2007) A multi-gene phylogeny of clavicipitaceae (ascomycota, fungi): identification of localized incongruence using a combinational bootstrap approach. Mol Phylogenet Evol 44:1204-1223

Tamura K, Peterson D, Peterson N, Stecher G, Nei M, Kumar S (2011) Mega5: molecular evolutionary genetics analysis using maximum likelihood, evolutionary distance, and maximum parsimony methods. Mol Biol Evol 28:2731-2739

White TJ, Bruns TD, Lee SB, Taylor JW (1994) Amplification and direct sequencing of fungal ribosomal RNA genes for phylogenetics. PCR Protoc 38:315-322
Wu HX, Wang J, Ding ZF, Liao BY (2007) Pathogen identification of wilt disease of Eucalyptus. Guangdong For Sci Technol 23:59-61

Xie BD, Ma BH, Hu XZ, Li XW (1993) The research on Fusarium wilt of Populus $\times$ euarmiereana (Dode) Guinier. J Cent South Univ For Technol 1:25-33

Yli-mattila T, Paavanen-Huhtala S, Parikka P, Konstantinova P, Gagkaeva T (2004) Molecular and morphological diversity of Fusarium species in Finland and North-Western Russia. Eur J Plant Pathol 110:573-585

Zhou XG, Everts K, Bruton BD (2010) Race 3, a new and highly virulent race of Fusarium oxysporum f. sp. niveum causing Fusarium wilt in watermelon. Plant Dis 94:92-98

Publisher's Note Springer Nature remains neutral with regard to jurisdictional claims in published maps and institutional affiliations. 